\title{
The Yield and Winter Hardiness of Selected Welsh Onion (Allium fistolosum L.) Cultivars Grown in Soil Fertilized with Polimag® S
}

\author{
Joanna Majkowska-Gadomska ${ }^{1}$, Katarzyna Arcichowska-Pisarska ${ }^{1} \&$ Artur Dobrowolski $^{1}$ \\ ${ }^{1}$ University of Warmia and Mazury in Olsztyn, Olsztyn, Poland \\ Correspondence: Joanna Majkowska-Gadomska, University of Warmia and Mazury in Olsztyn, Olsztyn, Poland. \\ Email: majkowska-gadomska@uwm.edu.pl
}

\author{
Received: December 19, 2013 Accepted: March 25, 2014 Online Published: April 15, 2014 \\ doi:10.5539/jas.v6n5p91 URL: http://dx.doi.org/10.5539/jas.v6n5p91
}

\begin{abstract}
Welsh onion (Allium fistulosum L.) is grown in Olsztyn (NE Poland) on an area of 4.0 ha. The habitat conditions in the Warmia region are conducive to growing new Welsh onion varieties as annual crops for selective harvesting. A two-factorial field experiment was conducted in a randomized block design with there replications in the Experimental Garden of the University of Warmia and Mazury in Olsztyn in 2009 - 2012. Seeds of three Welsh onion cultivars, Long White Ishikura, Parade and Performer were used. The effects of the following experimental factors were determined: Welsh onion cultivars Long White Ishikura, Parade and Performer grown from seedlings; the application of a mixed fertilizer, Polimag ${ }^{\circledR} \mathrm{S}$, at two rates of $0.72 \mathrm{t} \mathrm{ha}^{-2}$ and $1.44 \mathrm{t} \mathrm{ha}^{-2}$, referred to as $50 \%$ and $100 \%$ rates. The studied Welsh onion cultivars did not differ significantly with respect to yield, although an increase was noted in the total yield of Welsh onion leaves cv. Performer. Polimag® $\mathrm{S}$ applied at a $50 \%$ and $100 \%$ rate significantly increased the total yield of Welsh onion leaves. However, fertilization rate should not be increased above the $50 \%$ level since Welsh onion bulb yields were comparable at $50 \%$ and $100 \%$ rates of Polimag ${ }^{\circledR}$ S. During three consecutive growing seasons, Welsh onion plants cv. Long White Ishikura were characterized by the highest winter hardiness.
\end{abstract}

Key words: yield, winter hardiness, Welsh onion, Polimag ${ }^{\circledR}$ S.

\section{Introduction}

In Poland, the Welsh onion (Allium fistulosum L.) is grown on a small scale only, while it is widespread and widely used in the Far East. Due to their mild, sweet flavor and delicate consistency, whole Welsh onion plants are used as ingredients in various dishes. Recent years have witnessed a growing popularity of Welsh onions in Polish cuisine, particularly on the spring menu (Rabinowitch \& Brewster, 1990; Tendaj \& Mysiak, 2004; Kotlinska et al., 2006).

The yield and quality of Welsh onions are determined by the cultivar and the cultivation method, including an adequate supply of nutrients. Advanced fertilization programs rely on compound fertilizers that meet the specific nutrient requirements of different crop species. Species of the subfamily Allioideae should be fertilized in spring with Polimag ${ }^{\circledR} S$ - a next-generation mixed fertilizer that contains sulfur trioxide. This chemical compound is recommended for plants that are sensitive to chloride. Polimag ${ }^{\circledR} \mathrm{S}$ can be mixed with urea, ammonium nitrate and nitro-chalk before sowing, and with potassium sulfate at any time before application (Filipek-Mazur \& Gondek, 2005).

The varieties recommended for cultivation in north-eastern Poland are not genetically conditioned to survive over winter, therefore only cultivars such as Long White Ishikura can be grown as perennials.

The objective of this study was to determine the effect of Polimag® $\mathrm{S}$ applied at two rates on the yield of Welsh onions, and to evaluate the winter hardiness and suitability of three Welsh onion cultivars for field-growing in the Olsztyn region.

\section{Materials and Methods}

A two-factorial field experiment was conducted in a randomized block design with there replications in the Experimental Garden of the University of Warmia and Mazury in Olsztyn in 2009 - 2012. Seeds of three Welsh onion cultivars, Long White Ishikura, Parade and Performer were used. Welsh onion cultivars (Long White Ishikura, Parade and Performer) grown from seedlings, and the application of a mixed fertilizer, Polimag® S, at 
two rates $\left(0.72 \mathrm{t} \mathrm{ha}^{-2}\right.$ and $\left.1.44 \mathrm{t} \mathrm{ha}^{-2}\right)$ referred to as $50 \%$ and $100 \%$ rates were evaluated. Polimag® $\mathrm{S}$ contained $10 \% \mathrm{~N}, 8 \% \mathrm{P}, 15 \% \mathrm{~K}$ and $35 \% \mathrm{~S}$.

Each year between March 14 and 20, seedlings were grown in boxes $(50 \mathrm{~cm}$ x $30 \mathrm{~cm})$ in a greenhouse. The seedlings were prepared in line with the onion planting guidelines. The substrate used for seedling production was highmoor peat saturated with minerals and nutrients. Temperature data were provided by the Hydrological and Meteorological Station in Olsztyn. The winter severity index (Woz) was calculated for December-March of 2009-2012, on a 0-10-point scale (0 - very mild, 10 - very severe).

$$
W o z=(1-0.25 \cdot t) \cdot 0.832+0.014 \cdot d_{z}+0.009 \cdot d_{m}+0.005 \cdot d_{b m}-0.003 \cdot S_{t}
$$

where: $\mathrm{t}$ - average winter temperature in ${ }^{\circ} \mathrm{C}$ (from December to March), $\mathrm{d}_{\mathrm{z}}$ - number of winter days with average daily temperature of $\leq 0^{\circ} \mathrm{C}$ (December - March), $\mathrm{d}_{\mathrm{m}}$ - number of winter days with maximum temperature below $0^{\circ} \mathrm{C}$ (December - March), $\mathrm{d}_{\mathrm{bm}}-$ number of winter days with minimum temperature below $-10^{\circ} \mathrm{C}, \mathrm{S}_{\mathrm{t}}-$ total average daily air temperature below $0^{\circ} \mathrm{C}$ (December - March).

In each year of the study, the field was prepared for planting according to the standard recommendations for species of the subfamily Allioideae. Autumn ploughing and spring cultivation were carried out. To determine the basal fertilizer requirements of plants, the mineral content of soil was analyzed every spring. The soil was found to be abundant in phosphorus and potassium, and no supplemental fertilization with these elements was needed throughout the experiment. Due to low nitrate nitrogen content of soil, nitrogen was applied at a single dose of $30 \mathrm{~kg} \cdot \mathrm{ha}^{-1}$ in the form of ammonium nitrate before transplanting the seedlings. Polimag ${ }^{\circledR}$ S, applied at two different rates, was mixed with soil before transplanting the seedlings. Seedlings at the two- or three-leaf stage were individually planted in the field between 17 and 26 April. Forty-two seedlings were planted at the $20 \mathrm{~cm} x$ $30 \mathrm{~cm}$ spacing.

Welsh onion leaves were harvested by cutting with a knife ca. $5 \mathrm{~cm}$ above the ground. Dates of harvest were June 29, July 29 and August 24, 2009; July 12 and September 9, 2010, and June 27, July 19 and September 8, 2011. Each year, after the last harvest, plants were left to overwinter in the ground. The percentage of Welsh onion plants that survived through the winter, relative to transplanted plants, was calculated in early spring.

The results pertaining to the yield and quality of Welsh onions obtained in each year of the study were analyzed statistically by ANOVA. The significance of differences between means was estimated using Tukey's confidence intervals at a 5\% significance level.

\section{Results and Discussion}

The interactions between weather factors play an important role in crop production (Gajc-Wolska et al., 2005; Wierzbicka \& Majkowska-Gadomska, 2005; Grabowska \& Banaszkiewicz, 2009). In the Masurian Lakeland, climate conditions vary over space and time due to considerable differences between local habitats. The region is characterized by the presence of numerous water bodies and forests, and diversified land relief. Average daily air temperatures in the city of Olsztyn are lower than in other regions of Poland (Hutorowicz et al., 1991; Kozminski \& Michalska, 2001; Grabowski et al., 2007).

Welsh onions are cold-resistant and can grow at several degrees above zero. The plants can tolerate periods of excessive soil moisture and partial shade. The green tops get tough during drought. Due to significant rainfall deficiencies in 2009-2011, particularly in April, before transplanting the seedlings, soil moisture deficits were compensated for by sprinkling irrigation since insufficient rainfall prevents seedlings from taking root. Weather conditions in each year of the study are presented in Table 1 and Figure 1. 
Table 1. Average ten-day and monthly temperatures $\left({ }^{\circ} \mathrm{C}\right)$ of Olsztyn, from $2009-2012^{\text {Note }}$

\begin{tabular}{|c|c|c|c|c|c|c|c|c|c|c|c|c|c|}
\hline \multirow{2}{*}{ Year } & \multirow{2}{*}{$\begin{array}{l}\text { Ten-day } \\
\text { periods }\end{array}$} & \multicolumn{12}{|c|}{ Month } \\
\hline & & January & February & March & April & May & June & July & August & September & October & November & December \\
\hline \multirow{4}{*}{2009} & I & & & & 7.9 & 12.0 & 12.2 & 18.8 & 18.9 & 16.0 & 8.7 & 2.6 & 3.6 \\
\hline & II & - & - & - & 8.0 & 11.1 & 13.8 & 19.4 & 17.1 & 13.6 & 3.1 & 5.7 & -6.9 \\
\hline & III & & & & 12.1 & 14.0 & 18.8 & 19.3 & 16.8 & 12.9 & 5.7 & 6.9 & -2.3 \\
\hline & Average & - & - & - & 9.3 & 12.3 & 15.0 & 19.2 & 17.6 & 14.2 & 5.8 & 5.1 & -1.9 \\
\hline \multirow{4}{*}{2010} & I & -7.1 & -6.5 & -2.8 & 6.5 & 10.8 & 18.2 & 20.0 & 20.7 & 11.8 & 6.0 & 7.1 & -6.5 \\
\hline & II & -8.5 & -2.6 & 0.3 & 8.4 & 12.2 & 15.5 & 23.3 & 21.0 & 12.8 & 3.7 & 7.0 & -8.5 \\
\hline & III & -11.2 & 0.7 & 8.4 & 9.3 & 12.9 & 15.6 & 20.1 & 16.6 & 11.5 & 5.4 & -1.1 & -5.6 \\
\hline & Average & -8.9 & -2.8 & 2.0 & 8.1 & 12.0 & 16.4 & 21.1 & 19.4 & 12.0 & 5.0 & 4.3 & -6.9 \\
\hline \multirow{4}{*}{2011} & I & -1.1 & 1.6 & -2.5 & 8.1 & 8.7 & 18.8 & 17.1 & 18.2 & 14.4 & 12.6 & 4.8 & 2.9 \\
\hline & II & 1.1 & -7.4 & 2.9 & 6.3 & 14.2 & 15.4 & 19.2 & 16.9 & 14.6 & 6.3 & 0.8 & 2.4 \\
\hline & III & -4.3 & -13.0 & 4.1 & 12.9 & 16.2 & 16.9 & 17.6 & 17.7 & 13.4 & 6.2 & 3.7 & 1.7 \\
\hline & Average & -1.4 & -6.3 & 1.5 & 9.1 & 13.0 & 17.0 & 18.0 & 17.6 & 14.1 & 8.4 & 3.1 & 2.3 \\
\hline \multirow{4}{*}{2012} & I & 2.2 & -17.7 & -0.4 & & & & & & & & & \\
\hline & II & -1.9 & -5.4 & 4.0 & - & - & - & - & - & - & - & - & - \\
\hline & III & -6.1 & 1.4 & 5.3 & & & & & & & & & \\
\hline & Average & -1.9 & -7.2 & 3.0 & - & - & - & - & - & - & - & - & - \\
\hline
\end{tabular}

Note: Temperature data were provided by the Hydrological and Meteorological Station in Olsztyn.

In April 2009, air temperature was $2.4^{\circ} \mathrm{C}$ higher compared with the long-term average of 1961-2000. In May and June 2009 , air temperatures increased to $12.3^{\circ} \mathrm{C}$ and $15.0^{\circ} \mathrm{C}$, respectively, but the noted values were by $0.4^{\circ} \mathrm{C}$ and $0.9^{\circ} \mathrm{C}$ lower than the respective forty-year averages. In July, air temperature reached $19.2^{\circ} \mathrm{C}$ and it was $1.5^{\circ} \mathrm{C}$ higher than the long-term average. In August and September, air temperatures were $0.4^{\circ} \mathrm{C}$ and $1.7^{\circ} \mathrm{C}$ higher, respectively, than the forty-year averages for those months. In October, during the fall rest period, temperature dropped to $5.8^{\circ} \mathrm{C}$, and it was $2.0^{\circ} \mathrm{C}$ lower in comparison with the forty-year average. November was warmer (by $2.4^{\circ} \mathrm{C}$ ) and December was cooler (by $0.6^{\circ} \mathrm{C}$ ) than in the $1961-2000$ period. In 2009 , the winter severity index reached 2.49 , indicating a mild winter.

The year 2010 was characterized by low air temperatures, especially in January and February. The winter severity index reached 4.54, pointing to a cold winter, which affected plant survival in the field. Air temperature started to rise in March. Mean air temperature in April was $1.2^{\circ} \mathrm{C}$ higher than the long-term average. Air temperature decreased by $0.7^{\circ} \mathrm{C}$ in May, and increased by $0.5^{\circ} \mathrm{C}, 3.4^{\circ} \mathrm{C}$ and $2.2^{\circ} \mathrm{C}$ in June, July and August, respectively. A drop in air temperature was noted in September. November was warmer than average, similarly as in 2009. A further drop in temperature was observed in December, and it the middle of the month air temperature reached $-8.5^{\circ} \mathrm{C}$.

In 2011, January was cold, but warmer than average. The coldest month was February - air temperature dropped to $-13.0^{\circ} \mathrm{C}$, which had an adverse effect on overwintering success. A rise in temperature was noted in mid-March. In April, mean air temperature was $2.2^{\circ} \mathrm{C}$ higher than the long-term average. Mean air temperatures were conducive to plant growth over the entire growing season. November and December 2011 were warmer than average. The winter severity index reached 2.02 .

In 2012, the experiment was continued until March. In the last week of January and in the first week of February, air temperatures decreased to $-6.1^{\circ} \mathrm{C}$ and $-17.7^{\circ} \mathrm{C}$, respectively, which affected the percentage of plants that survived winter. 


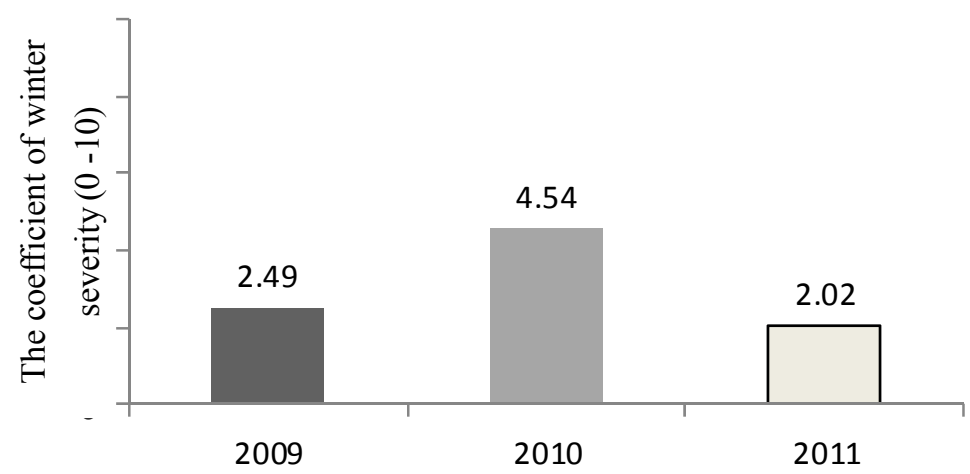

Figure 1. Winter severity index of Olsztyn from 2010-2012

In all years of the study, the total yield of Welsh onion leaves constituted the marketable yield (Table 2). The studied cultivars of Welsh onions were grown as isolated plants. The leaves of Welsh onions are thick, fleshy, tubular, dark green, hollow and cylindrical, and they have a mild flavor (Bremnessova, 2004). The Welsh onion does not develop bulbs, but a white to light green stem which has delicate consistency and high nutritional value (Kotlinska et al., 2006). New Welsh onion varieties, with elongated tube-like hollow leaves, may be a viable alternative to common onions grown from small bulbs for early bunch harvest (Kolota et al., 2013). In the present experiment, Welsh onion yield was affected by weather conditions. The highest and lowest yields of selectively harvested leaves were obtained in 2011 and 2010, respectively.

Table 2. Effects of different cultivars and Polimag ${ }^{\circledR} \mathrm{S}$ rates on yield $\left(\mathrm{t} \mathrm{ha}^{-1}\right)$ of Welsh onion leaves

\begin{tabular}{|c|c|c|c|c|c|}
\hline \multirow{3}{*}{ Cultivar } & \multirow{3}{*}{ Treatments $^{\text {note }}$} & \multicolumn{4}{|c|}{ Year } \\
\hline & & 2009 & 2010 & 2011 & Mean \\
\hline & & \multicolumn{4}{|c|}{ Total yield } \\
\hline \multirow{4}{*}{ Long White Ishikura } & Control & 13.0 & 4.6 & 18.2 & 11.9 \\
\hline & $50 \%$ & 20.9 & 7.4 & 19.5 & 11.6 \\
\hline & $100 \%$ & 17.4 & 9.2 & 20.7 & 15.8 \\
\hline & Mean & 17.0 & 7.1 & 19.5 & 13.1 \\
\hline \multirow{4}{*}{ Parade } & Control & 13.7 & 6.4 & 13.0 & 11.0 \\
\hline & $50 \%$ & 16.0 & 8.3 & 21.0 & 15.1 \\
\hline & $100 \%$ & 15.9 & 10.4 & 18.9 & 15.1 \\
\hline & Mean & 15.2 & 8.4 & 17.6 & 13.7 \\
\hline \multirow{4}{*}{ Performer } & Control & 13.5 & 3.8 & 14.8 & 10.7 \\
\hline & $50 \%$ & 22.7 & 6.1 & 24.2 & 17.7 \\
\hline & $100 \%$ & 22.2 & 9.1 & 19.9 & 17.1 \\
\hline & Mean & 19.4 & 6.3 & 19.6 & 15.2 \\
\hline \multirow{3}{*}{ Mean } & Control & 13.3 & 5.0 & 15.4 & 11.2 \\
\hline & $50 \%$ & 19.9 & 7.2 & 21.6 & 16.2 \\
\hline & $100 \%$ & 18.5 & 9.6 & 19.8 & 16.0 \\
\hline \multicolumn{6}{|l|}{$\mathrm{LSD}_{0.05}$} \\
\hline Cultivar & & n.s. & n.s. & n.s. & n.s. \\
\hline Treatments & & 3.4 & 1.3 & 2.6 & 2.1 \\
\hline Interaction & & 5.1 & 0.9 & 2.4 & 2.6 \\
\hline
\end{tabular}

Control - $0 \mathrm{t} \mathrm{ha}^{-2}$ Polimag ${ }^{\circledR} \mathrm{S}, 50 \%-0.72 \mathrm{t} \mathrm{ha}^{-2}$ Polimag ${ }^{\circledR} \mathrm{S}, 100 \%-1.44 \mathrm{t}$ ha ${ }^{-2}$ Polimag ${ }^{\circledR}$ S. 
Analysis of variance did not indicate significant differences among the yield of harvested onion leaves, which was significantly affected by fertilization (Polimag ${ }^{\circledR} S$ ) in all years of the study. According to Kaniszewski et al. (1987), Rozek (2000), Kolota \& Adamczewska-Sowinska (2007a, b), yield of vegetable crops is determined by fertilization. Welsh onions require intensive organic and mineral fertilization at $200 \mathrm{~kg} \mathrm{ha}^{-1} \mathrm{~N}, 150 \mathrm{~kg} \mathrm{ha}^{-1} \mathrm{P}_{2} \mathrm{O}_{5}$, $175 \mathrm{~kg} \mathrm{ha}^{-1} \mathrm{~K}_{2} \mathrm{O}$ (Brewster, 2008). Positive effects of Polimag ${ }^{\circledR} \mathrm{S}$ and Polimag 305 in the cultivation of other plant species have been reported by Grzeskiewicz and Trawczynski (1998), Filipek-Mazur and Gondek (2005). In our study, an increase in the yield of Welsh onion leaves harvested from plots fertilized with Polimag® $\mathrm{S}$ at a $50 \%$ rate was noted in 2009 and 2010. In 2010, the yield Welsh onion leaves increased significantly in the treatment with Polimag ${ }^{\circledR}$ S at a $100 \%$ rate. Different results were reported by Kolota et al. (2013) who found that increased pre-plant nitrogen from 75 to 150 and $225 \mathrm{~kg} \mathrm{ha}^{-1}$ had no influence on the yield and contributed to nitrate accumulation in plants.

In 2009, the total yield of Welsh onions was significantly affected by supplemental fertilization and the interaction between the experimental factors. Supplemental fertilization significantly increased the total yield of Welsh onion leaves, relative to the control treatment, whereas no significant differences were found between the two rates of Polimag ${ }^{\circledR} \mathrm{S}$ with respect to Welsh onion yield. The highest yield was obtained in plants of cv. Performer from the treatment with Polimag® S at a 50\% rate, and lowest in plants of cv. Long White Ishikura from the control treatment. In 2010, the total yield of Welsh onions was significantly affected by the rate of Polimag ${ }^{\circledR}$ S and the fertilizer $x$ cultivar interaction. Polimag $®$ S applied at a $100 \%$ rate had a positive effect on the total yield of Welsh onion leaves. The highest yield increase was noted in plants of all three cultivars fertilized with Polimag ${ }^{\circledR}$ S at a $100 \%$ rate, and the lowest - in plants of cvs. Long White Ishikura and Performer from the control treatment. In 2011, Polimag ${ }^{\circledR}$ S applied at a 50\% rate had a significant, positive effect on the yield of Welsh onions cv. Performer, as compared with the control treatment.

In comparison with the control treatment, supplemental fertilization and the fertilizer $\mathrm{x}$ cultivar interaction had a significant, positive effect on the average yield of Welsh onion leaves determined for three years of the study (Figures 2, 3, 4). Polimag ${ }^{\circledR}$ S contributed to an increase in the average three-year yield, compared with the control treatment. The differences in the yield-forming effect between two Polimag $\mathbb{B}$ S rates $(50 \%$ and $100 \%)$ were not significant, which indicates that the $50 \%$ rate was sufficient to gain economic benefits. The total yield of Welsh onions in our experiment was comparable with those reported by Grubben (1994), Tendaj and Mysiak (2007), Grevsen (1989), Leong (2001), Lazic et al. (2002) and Kolota et al. (2012), but lower than that obtained by Jadczak and Zurawik (2004). According to Biesiada et al. (2007), Kolota and Adamczewska-Sowinska (2007a), the Welsh onion yield achieved in the Far East is similar to the leek yield attained in Poland. In a study by Permadi (1994), the Welsh onion yield ranged from 60 to $80 \mathrm{t} \mathrm{ha}^{-1}$. The total yield of Welsh onion leaves in the current experiment was comparable with the yield of chives obtained by Zurawik and Jadczak (2008).

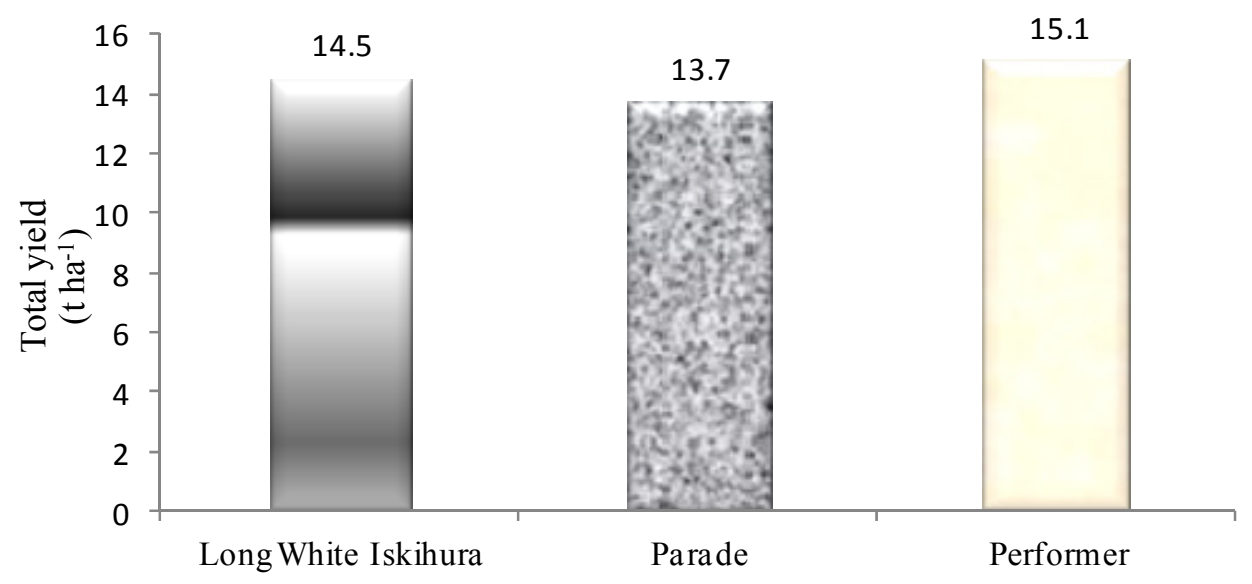

Figure 2. Effects of different cultivars on total yield of Welsh onion leaves in Olsztyn from 2009-2011 


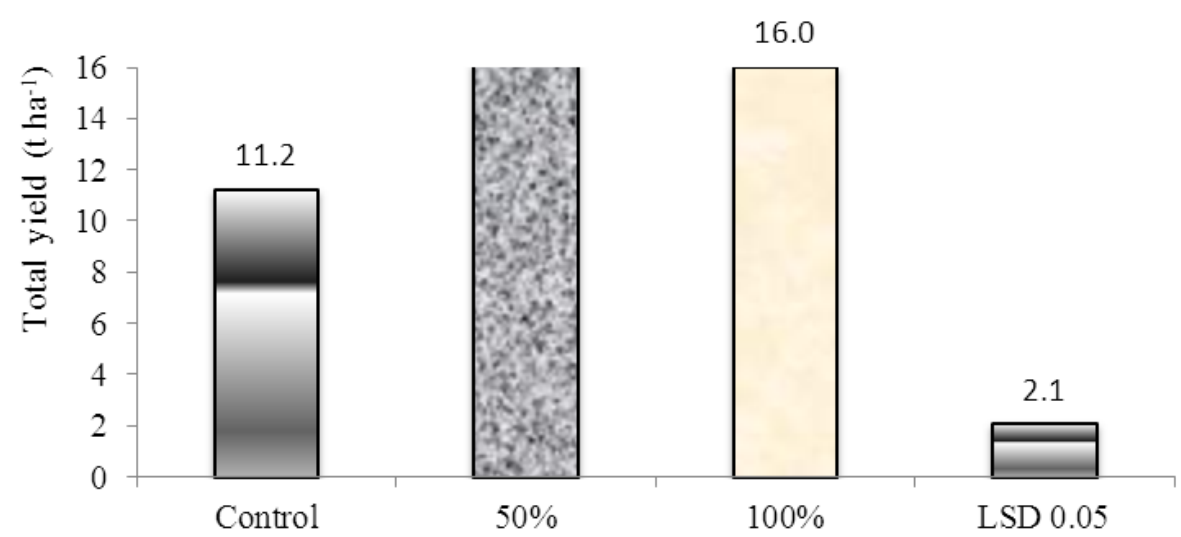

Figure 3. Effects of Polimag ${ }^{\circledR}$ S on total yield of Welsh onion leaves in Olsztyn from 2009-2011

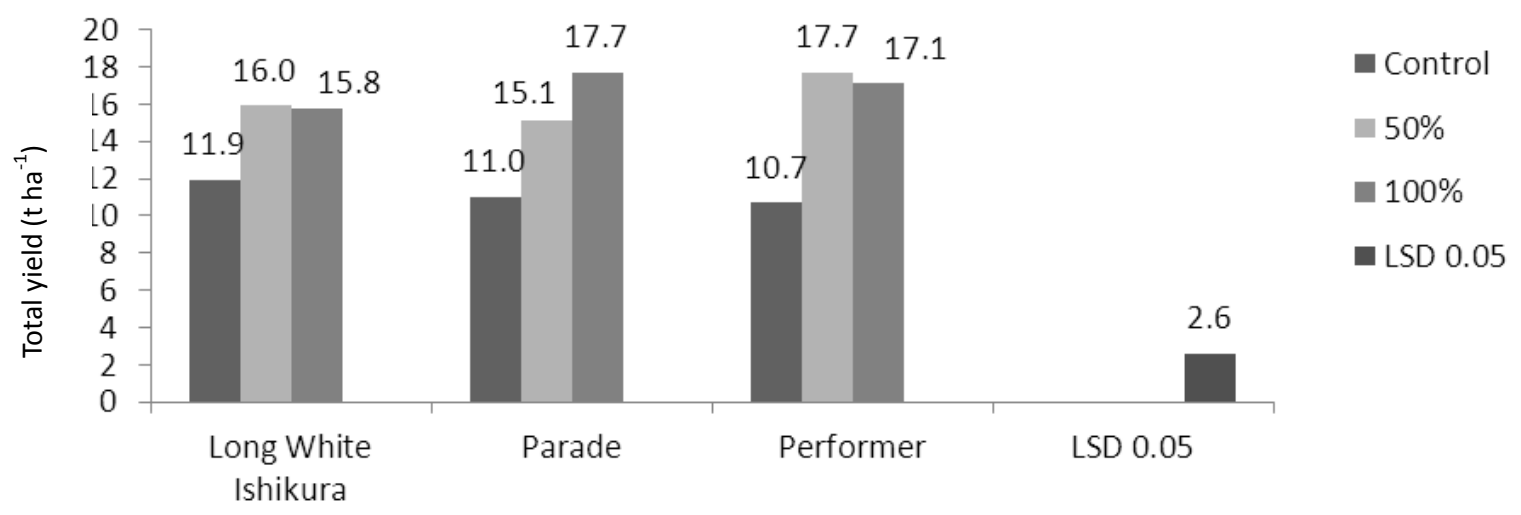

Figure 4. Effects of different cultivars and Polimag ${ }^{\circledR}$ S rates on total yield of Welsh onion leaves in Olsztyn from 2009-2011

Felczynski (2010) reported that weather conditions during the growing season had a significant effect on the frost tolerance of winter onions. Kolota and Adamczewska-Sowinska (2007a) demonstrated that the winter hardiness of leek plants may be improved by applying covers.

Among the analyzed Welsh onion cultivars, only Long White Ishikura is genetically adapted to overwintering, whereas Parade and Performer are annual cultivars intended for harvest as whole plants. In the Olsztyn region, Welsh onions are at risk of frost damage. The average percentage of Welsh onion plants that survived through the winter, relative to all transplanted plants, ranged from $9.2 \%$ to $18.6 \%$ in the three years of the study (Table 3 ). Welsh onion plants cv. Long White Ishikura and cv. Parade were characterized by the highest and lowest winter hardiness, respectively. An analysis of the winter hardiness of three Welsh onion cultivars in $2009-2012$ revealed that Long White Ishikura and Performer plants had the highest survival rates in the 2009/2010 winter (13.0\% and 13.9\%, respectively), Long White Ishikura in 2010/2011 (19.4\%), and Parade in 2011/2012 (21.3\%). 
Table 3. Percentage of Welsh onion plants that survived through the winter in each year of the study

\begin{tabular}{|c|c|c|c|c|c|}
\hline \multirow{2}{*}{ Cultivar } & \multirow{2}{*}{ Treatments $^{\text {note }}$} & \multicolumn{3}{|c|}{ Year } & \multirow{2}{*}{ Mean } \\
\hline & & $2009 / 2010$ & $2010 / 2011$ & $2011 / 2012$ & \\
\hline \multirow{3}{*}{ Long White Ishikura } & Control & 8.3 & 22.2 & 25.0 & 18.6 \\
\hline & $50 \%$ & 5.6 & 16.7 & 5.6 & 9.2 \\
\hline & $100 \%$ & 25.0 & 19.4 & 5.6 & 16.7 \\
\hline \multirow[t]{2}{*}{ Mean } & & 13.0 & 19.4 & 12.1 & 14.8 \\
\hline & Control & 8.3 & 5.6 & 13.9 & 9.2 \\
\hline \multirow[t]{2}{*}{ Parade } & $50 \%$ & 5.6 & 2.8 & 25.0 & 11.1 \\
\hline & $100 \%$ & 0.0 & 16.7 & 25.0 & 13.9 \\
\hline \multirow[t]{2}{*}{ Mean } & & 4.6 & 8.4 & 21.3 & 11.4 \\
\hline & Control & 11.1 & 16.7 & 11.1 & 13.1 \\
\hline \multirow[t]{2}{*}{ Performer } & $50 \%$ & 8.3 & 0.0 & 22.2 & 10.3 \\
\hline & $100 \%$ & 22.2 & 13.9 & 11.1 & 15.8 \\
\hline Mean & & 13.9 & 10.2 & 14.8 & 13.1 \\
\hline
\end{tabular}

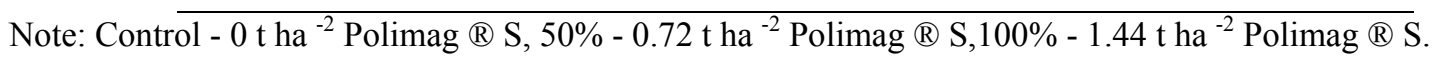

\section{Conclusions}

The habitat conditions in the Warmia region are conducive to growing new Welsh onion varieties as annual crops for selective harvesting.

The studied Welsh onion cultivars did not differ significantly with respect to yield, although an increase was noted in the total yield of Welsh onion leaves of cv. Performer.

Polimag ${ }^{\circledR} \mathrm{S}$ applied at $0.72 \mathrm{t} \mathrm{ha}^{-2}$ and $1.44 \mathrm{tha}^{-2}$ significantly increased the total yield of Welsh onion leaves harvested selectively.

Fertilization rate should not be increased above the $50 \%$ level since Welsh onion yields were comparable at $0.72 \mathrm{t}$ $\mathrm{ha}^{-2}$ and $1.44 \mathrm{t} \mathrm{ha}^{-2}$ rates of Polimag® S.

During three consecutive growing seasons, Welsh onion plants cv. Long White Ishikura were characterized by the highest winter hardiness, but the noted results were not satisfactory from the producers' point of view.

\section{Acknowledgements}

The study was financed as part of research project No. 1014.0804.

\section{References}

Biesiada, A., Kolota, E., \& Adamczewska-Sowinska, K. (2007). The effect of maturity stage on nutritional value of leek, zucchini and kohlrabi. Veg. Crops Res. Bull., 66, 39-45.

Bremnessova, L. (2004). Bylinky. Vyd. Ikar, Bratislava.

Brewster, J. L. (2008). Onions and other vegetable alliums. Crop Prod. Science in Hort (No. 15, pp. 14-19). Wallingford, Oxfordshire, UK: CABI. http://dx.doi.org/10.1079/9781845933999.0000

Felczynski, K. (2010). Effects of cultivars and autumn planting of scallions on winter hardiness and yield. Proceedings of the Scientific Conference "Growing Organic Vegetables - Challenges and Prospects", 24-25 June Siedlce, Poland, 53-54 (in Polish).

Filipek-Mazur, B., \& Gondek, K. (2005). Effect of sulfur-based fertilizers on the yield and sulfur content of white mustard. Acta Agrophys, 6(2), 343-351 (in Polish).

Gajc-Wolska, J., Zielony, T. \& Radzanowska, J. (2005). Yield and quality of sweet peppers (Capsicum annuum L.). Zesz. Nauk. Akad. Rol. Wroc., Rol. LXXXVI, 515, 139-147 (in Polish).

Grabowska, K., \& Banaszkiewicz, B. (2009). Effects of air temperature and precipitation on pea yield in Central Poland. Acta Agrophys, 13(1), 113-120 (in Polish). 
Grabowska, K., Banaszkiewicz, B., \& Szwejkowski, Z. (2004). Rainfall deficit and excess in the Region of Warmia and Mazury in 2000-2002. Acta Agrophys, 3(1), 57-64 (in Polish).

Grabowski, J., Olba-Ziety, E., \& Grabowska, K. (2007). A comparison of weather conditions in two mesoregions and their effect on potato yield. Acta Agrophys, 9(2), 353-359 (in Polish).

Grevsen, K. (1989). Effects of sowing dates on different varieties of Welsh onion (Allium fistulosum L.) under temperature coastal climate. Acta Hort., 242, 319-324.

Grubben, G. J. H. (1994). Constraints for shallot, garlic and Welsh onion in Indonesia: A case study on the evolution of Allium crops in the equatorial tropice. Acta Hort., 358, 333-339.

Grzeskiewicz, H., \& Trawczynski, C. (1998). Effect of Polifoska ${ }^{\circledR}$ compound fertilizers on the yield and quality of potato tubers. Fol. Univ. Agric. Stein. Agricultura, 72, 81-85 (in Polish).

Hutorowicz, H., Nowicka, A., Grabowska, K., \& Grabowski, J. (1991). Characteristics of agro-climatic conditions in north-eastern Poland. Zesz. Nauk. AR Kraków. Ogrod, 27(246), 23-37 (in Polish).

Jadczak, D., \& Zurawik, A. (2004). Effects of seeding dates and rates on the yield and quality of Welsh onions cv. Sprint. Folia. Univ. Agric. Stetn. Agricultura, 239(95), 161-164 (in Polish).

Kaniszewski, S., Elkner, K. \& Rumpel, J.(1987). Effect of nitrogen fertilization and irrigation on field, nitrogen status In plants and fruits of direct seed tomatoes. Acta Hort., 200, 195-202.

Kolota, E. \& Adamczewska-Sowinska, K. (2007a). The effects of flat covers on overwintering and nutritional value of leeks. Veget. Crops Res. Bull., 66, 11-16.

Kolota, E. \&Adamczewska-Sowinska, K.(2007b). Effect of Entec 26 fertilizer on the yield of early-harvest leeks. Rocz. AR Pozn. CCCLXXXIII, Ogrodn, 41, 529-532 (in Polish).

Kolota, E., Adamczewska-Sowinska, K., \& Uklanska-Pusz, C. (2012). Yield and nutritional value of Japanese bunching onion (Allium fistulosum L.) depending on the growing season and plant maturation stage. $J$. Elementol., 17(4), 587-596. http:dx.doi.org/10.5601/jelem.2012.17.4.03

Kolota, E., Adamczewska-Sowinska, K., \& Uklanska-Pusz, C. (2013). Response of Japanese bunching onion (Allium fistulosum L.) to nitrogen fertilization. Acta Sci. Pol. Hortorum Cultus, 12(2), 51-61.

Kotlinska, T., Kaniszewski, S., \& Kwiecień, A. (2006). Methods of Welsh onion cultivation. Hasło Ogrodnicze, 6 , 82-86 (in Polish).

Kozminski, C., \& Michalska, B. (2001). Atlas of climatic risk to crop cultivation in Poland. In A. R. Szczecin (Ed.) (in Polish).

Lazic B., Todorovic V., Dardic M. (2002). Effect of production method on earliness and field of Allium fistulosum L. Acta Hort., 579, 359-362.

Leong, A. C. (2001). Performance of bunching onion (Allium fistulosum L.) cultivars in the low lands of tropical Malaysia. Acta Hort., 555, 99-101.

Malý, I. (1994). Effect of non-woven fabric (AGRYL 17) on the winter hardiness and quality of leeks. Proceedings of the Scientific Conference "New Technologies for Growing Bulbous Vegetables", 23-24 June 1994, Szczecin, Poland: 30-33 (in Polish).

Permadi, A. H. 1994. Allium production and research status in Indonesia. Acta Hort., 358, 87-93.

Rabinowitch, H. D., \& Brewster, J. L. (1990). Onions and allied crops. Botany, Physiology, and Genetics. Boca Raton, Florida, USA: I. CRC Press Inc.

Rozek, S. (2000). Determinants of nitrate accumulation in vegetable crops. Zesz. Nauk. AR Kraków, 364(71), 19-31 (in Polish).

Tendaj, M. \& Mysiak, B. (2007). Effects of seedling transplanting time and flat covers on the yield of Welsh onions (Allium fistulosum L.). Annales UMCS, sec. EEE, Horticultura, XVII(2), 5-10 (in Polish).

Tendaj, M., \& Mysiak, B. (2004). Suitability of Welsh onions for early bunch harvest. OWK, 9, 14 (in Polish).

Wierzbicka, B., \& Majkowska-Gadomska, J. (2005). Yield and concentrations of some bionutrients in parthenocarpic cucumber fruits in forced cultivation. Zesz. Probl. Post. Nauk Roln., 507, 569-574 (in Polish).

Zurawik, A., \& Jadczak, D. (2008). Effects of cultivation method and seeding or planting rates on the yield and quality of garlic chives (Allium tuberosum ROTTLER ex SPRENG.). Zesz. Probl. Post. Nauk Rol., 527, 343-349 (in Polish). 


\section{Copyrights}

Copyright for this article is retained by the author(s), with first publication rights granted to the journal.

This is an open-access article distributed under the terms and conditions of the Creative Commons Attribution license (http://creativecommons.org/licenses/by/3.0/). 